\title{
Chapter 5 \\ The Negative Female Educational Gradient of Union Dissolution: Towards an Explanation in Six European Countries
}

\author{
Maike van Damme
}

\begin{abstract}
How can we explain that, nowadays, lower educated women are more likely to separate than higher educated women are? I formulate hypotheses to explain this based on Levinger's (J Marriage Family 27(1):19-28, 1965; J Soc Issues 32(1):21-47, 1976; Handbook of interpersonal commitment and relationship stability. Kluwer Academic/Plenum Publishers, New York, 1999) social exchange theory on 'attractions' and 'barriers' and assess whether there are mediating effects of affectional rewards, economic rewards, symbolic rewards, affectional barriers, material barriers, and symbolic costs. I analyse the Generations and Gender Survey (GGS) [2004-2013] for two waves for Bulgaria, Russia, Georgia, France, Austria, and Czech Republic. With this selection of countries, I have a good context variation according to social and economic costs of union dissolution. Using the khb-approach - which is a mediation analysis for binary dependent variables - I examine the probability that women broke up between two consecutive waves and explain the influence of education on union dissolution. Instead of being mainly explained by 'attractions', 'barriers' were more important explanatory variables of the negative educational gradient of union dissolution in the six countries I studied (lower educated women had less to lose symbolically and economically). Next to relationship satisfaction as the only explanatory 'attraction', I found suppressor effects of 'attractions'.
\end{abstract}

Keywords Confounding $\cdot$ Education $\cdot \mathrm{Khb}$-method $\cdot$ Mediation analysis $\cdot$ Union dissolution

\subsection{Introduction}

Already in 1962, William Goode (1962) mentioned that in (Western) traditional (divorce is less common) contexts, the upper strata would divorce the most, whereas in more advanced (divorce is more common) contexts, the lower strata would be most likely to break up. One societal stratifying indicator is education. Educational

M. van Damme ( $\triangle)$

Pompeu Fabra University, Barcelona, Spain

e-mail: maike.vandamme@upf.edu 
inequalities exist in many aspects of life and family life events like divorce are no exception to this. Studying the mechanisms underlying the educational gradient of separation is of utmost scientific importance because a negative educational gradient might imply growing inequality for future generations in family behaviour. Individual-level explanations of educational differences in breaking-up have rarely been studied (but see Boertien and Härkönen 2018; Jalovaara 2001; Raymo et al. 2013). I try to unravel the different mediators explaining why higher educated women are less likely to break-up, i.e. what is referred to as the negative educational gradient. Research so far has demonstrated a change in the Nordic and Continental countries from a positive female educational 'gradient' - the higher educated are more likely to divorce than the lower educated - in earlier periods (from roughly the forties to the nineties) to a negative one in recent times (Matysiak et al. 2014).

Following social exchange theory of Levinger (1965, 1976), Boertien and Härkönen (2018) examined for the UK whether and to what extent the explanation lies in 'attractions' (measured by marital satisfaction) while controlling for 'barriers' (affectional, material, and symbolic costs, see below). This chapter differs in two important ways from the publication of Boertien and Härkönen and extends therefore prior recent research on this topic. First, Boertien and Härkönen examined only marital break-ups and could not investigate separations from cohabitations. In this chapter, I consider both break-ups from marital and cohabitational relationships. Second, Boertien and Härkönen found small educational differences in marital satisfaction; hence, this could explain the educational gradient of divorce in the UK only to a small extent. Yet, Van Damme and Dykstra (2018) found a robust positive educational effect (of the couple's level, not women's education only) on marital satisfaction for eight EU-countries. Could it be that marital satisfaction is a more important explanatory factor of educational differences in union dissolution in other countries than the UK? To find this out, I replicate the single country study of Boertien and Härkönen with studies in other (more) countries. My questions therefore are: To what extent are lower educated women more likely to break-up than higher educated women and how can I explain this? To what extent do 'attractions' and to what extent do 'barriers' have mediating roles, explaining this female educational gradient of union dissolution?

In answering these questions, I do not only replicate Boertien and Härkönen's study for other contexts than the UK (i.e. I look at West- and Eastern European contexts with a variation of social and economic costs of divorce). I also use explicitly more indicators of attraction than only marital satisfaction. With this, I widen the number of indicators of the concept of attractions, which makes the measurement of attractions more extensive and reliable.

I analyse the Generations and Gender Survey (GGS) [2004-2013] for two waves for the following six countries: Czech Republic, Austria, France, Georgia, Russia, and Bulgaria. Using logistic regression and the khb-approach (Karlson et al. 2012) for disentangling direct from indirect effects, I examine whether women have broken up their relationship since wave 1 and perform a mediation analysis to explain the female educational gradient of union dissolution. I only consider opposite sex relationships. 


\subsection{Theoretical Framework}

I apply George Levinger's $(1965,1976,1999)$ social-psychological social exchange theory to explain why the higher educated experience a lower break-up rate than the lower educated. Levinger addresses the cohesiveness of pairs in the same way as group cohesiveness, by considering both 'attractions to stay in the relationship' and 'barriers to leave the relationship'. When both partners have continuing positive feelings toward the other and at the same time some constraining feelings, ties, and structures, the pair commitment is strong. 'Attractions' are the balance of costs (time, energy, and other expenditures that are required for continuing a relationship) and benefits of the marriage (receipt of love, status, information, money, and other resources). They consist of affectional, material, and symbolic rewards. 'Barriers' are constraints to dissolution, such as having marital specific capital and marital commitment, that only play a role once the spouses are dissatisfied with the relationship or start thinking about breaking-up. Among such constraints are affectional, material, and symbolic costs. Note that Levinger $(1965,1976)$ also includes 'alternative attractions', which he defines as attractions from alternative relationships (e.g. including family or work relationships). Levinger points out that theoretically, someone would leave her/his current relationship if and when the benefits from the alternative situation exceed the benefits of the current relationship, if there were a complete absence of barriers. ${ }^{1}$ However, following Boertien and Härkönen (2014), I state that these alternative attractions can be considered 'barriers' to break up since a lack of alternatives creates such barriers. For instance, women's own occupational status and employment (both conceptualized here as barriers to breakup) can be seen as alternative attractions to live alone rather than together in a nonsatisfactory relationship.

Levinger discusses a set of determinants that were proven relevant in the American society of the sixties and seventies. I update the then relevant attractions and barriers explaining the break-up risk that were suggested by Levinger by adding a couple perspective (e.g. having not only his occupational status or income (as indicators of rewards), but also hers' (as indicators of costs)). Note that the GGS has some information on couple characteristics but are not full couple data.

I now first discuss Levinger's attractions and barriers in detail (based on Levinger, $(1965,1976))$ and then I formulate hypotheses of the mediating/confounding effects of these rewards and costs in explaining educational differences in union dissolution. In formulating the hypotheses (expectations) of the mediating relationships, I use the following conceptual models (Figs. 5.1a and 5.1b), which will be elaborated upon in the following section, where I discuss each attraction and barrier separately. I expect that attractions in general are explaining the relationship between education and separation, whereas barriers are suppressing this relationship.

\footnotetext{
${ }^{1}$ In a more recent article, Levinger (1999: p. 49) also distinguished a fourth factor: barriers of alternative relationships, which are defined as "psychological pressures from alternative states that interfere with carrying out one's commitment to the primary relationship."
} 


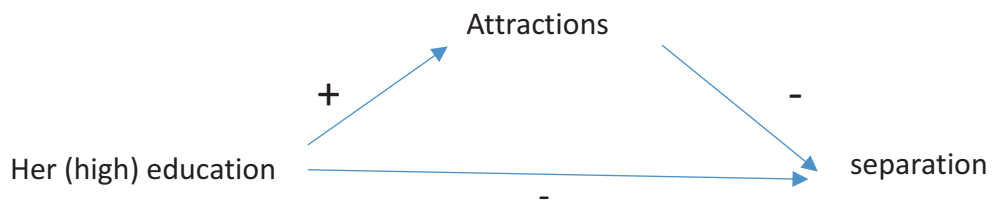

Fig. 5.1a Expected mediating mechanisms of the relationship between education and separation; attractions as mediators

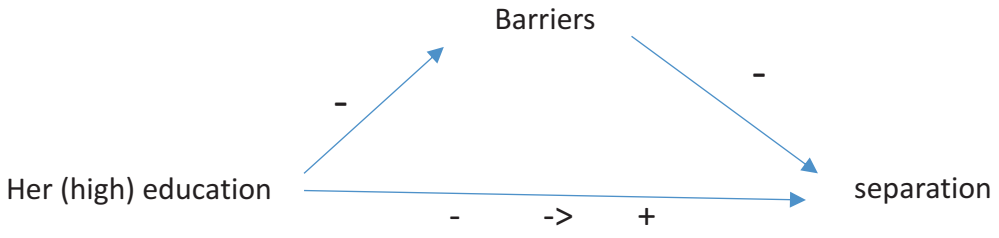

Fig. 5.1b Expected mediating mechanisms of the relationship between education and separation; barriers as mediators (suppressors)

\subsubsection{Attractions to Stay Together}

\subsubsection{Affectional Rewards}

Levinger distinguishes between companionship, esteem, and sexual enjoyment as measuring the affectional rewards of a relationship. He states that companionship has been strongly related to marital adjustment, esteem is reflected in few complaints about the spouse, and sexual enjoyment is related to marital satisfaction. I expect that higher educated women are more satisfied with their relationship (van Damme and Dykstra 2018) and those that are more satisfied will be less likely to break up (Karney and Bradbury 1995).

\subsubsection{Material Rewards}

Examples of material rewards are family income and joint homeownership. Oppenheimer (1997) argued, in her criticism of Gary Becker's specialization and trade model, that Becker did not take into account the inflexibility and riskiness of one-earner households and stated that one should consider the absolute level of standard of living of the couple (or the wife alone) to assess its' marital stability. Thus, one can expect from Oppenheimer's perspective that higher educated women are in couples with more financial resources and that such couples are less likely to break up because they are more flexible and have a less risky intra-household division of labour. I add to Levinger's determinants the possession of durables in the 
household as a measure of non-deprivation and his unemployment as an economic stressor, following Boertien and Härkönen (2018).

\subsubsection{Symbolic Rewards}

Among the rewards with a symbolic meaning, Levinger refers to the spouse's education and occupational status, next to similarity in social characteristics like education, religion, and age. These variables are indicators of a couple's social rank in society or status in the community. If she has a higher education, his education and social status are usually higher (in case of homogamy (e.g. Grow and Van Bavel 2015; Schwartz and Mare 2005)), but higher education may also be related to a higher income and thus a better living standard, better communication skills, and more importance of companionship with the spouse (Levinger 1976).

Social similarities like education and age similarities between the partners may reflect the couple's ability to communicate. In addition, educational similarity may go together with similar beliefs and attitudes, whereas age similarity with similar interests and physical health. Homogamous couples may thus be less likely to break up (Kalmijn et al. 2005; Petts 2016), although Levinger notes that this would apply less to hetereogamous couples who have "[...] free[d] themselves from the disjunctive forces of their social backgrounds" (Levinger 1976: p. 33), something that may have mattered more some decades ago than in nowadays society.

In any case, I will examine the mediating/confounding influence of educational similarity of the spouses, along with age difference. I expect that higher educated women are more likely to be in a homogamous or female hypergamous relationship (Schwartz and Han 2014). However, based on the aforementioned theoretical arguments, I do not have an expectation about the likelihood of breaking up of homogamous couples versus educational/age (dis)similar couples. I will also directly include conflict resolution skills of the couple to assess mediating effects of possible better communication among the higher educated (Amato 1996) and a negative association between communication and separation.

\subsubsection{Barriers to Leave the Relationship}

\subsubsection{Affectional Costs}

Dependent children are one example of affectional costs. Childless couples are found to be more likely to break up than couples with children (even after controlling for union duration) (Liefbroer and Dourleijn 2006). ${ }^{2}$ Some studies have pointed

\footnotetext{
${ }^{2}$ I could also place alternative attractions in the category of affectional costs. Having few potential partners of the opposite sex available around them can increase the threshold for women to break
} 
out that, even though the higher educated postpone having children more often than the lower educated, they catch up by having a smaller spacing period between consecutive childbirths and therefore the completed family size of higher educated mothers would be similar to those of lower educated ones (conditional upon age at first birth) (e.g. Castro Martin 2006). However, others demonstrated that a negative educational gradient of quantum fertility exists and that postponement played a large role in explaining this, at least in the UK (e.g. Berrington, Stone, and Beaujouan 2015). It is thus unclear what to expect when it comes to a mediating effect of having children on the association between her education and union dissolution depending upon whether I will find a relationship between her education and affectional costs (i.e. having (young) children).

\subsubsection{Material Costs}

Material costs may consist of all sorts of financial expenses such as the loss of economies of scale and divorce costs (e.g. filing for divorce, legal services, child maintenance), but also the home ownership status of the partner. If he owns a house and she does not, or he earns more than she does and she has little independent income, she loses more from the relationship than if her contribution is substantial. Thus, a woman can afford to break up more easily if she can support herself outside of the union (e.g. Sayer and Bianchi 2000; van Damme and Kalmijn 2014). I estimate economic independence by occupational status. The lower her status is, the more it would be a barrier to break up, just like her unemployment would be.

Women's independent social status might also matter in a different way though. In some cases, a woman might improve her financial situation if her husband was exploiting her financially (i.e. he uses most of the income for other than household purposes and consequently she (and the rest of the household) lives in poverty). Moreover, Levinger put forward that in the lower economic strata women would have less to lose materially than in the higher strata. The direction of a mediation effect of women's own occupational status is thus not entirely clear.

\subsubsection{Symbolic Costs}

Levinger states that marriage is also a "symbolic acknowledgement of one's place in a culture and in a kin network" (Levinger 1976: p. 36). He sums up obligational feelings towards the marital bond, religious constraints, and external pressure from primary groups and community. The first factor concerns commitment towards the partner: if a spouse is highly committed, the less likely she will break up or even think about breaking up. Previous divorce experiences and parental divorce are indicative of a person's tolerance to break up (Dronkers and Härkönen 2008;

up as they might not see a good alternative for the current spouse. Such alternative affectional costs could be proxied by the male/female ratio in a country or region, but because I do not expect to see a relationship with female education, I will not include such a variable. 
Poortman and Lyngstad 2007). Even though there might be differences between divorce risks of different religious denominations, having had a religious ceremony is positively related with marital stability, just like church attendance is. ${ }^{3}$ Connected kinship and friendship networks are also important for marital stability [e.g. the quality of intergenerational relationships, in-law relationships, and broader social contexts (Högnäs and Carlson 2010)], although in the case of disapproval by tight networks the divorce risk of the couple may be higher - this especially applies to women's network (Sprecher and Felmlee 1992). Small communities (rural areas) have lower divorce risks than larger ones due to larger social pressure and the couple's social visibility. ${ }^{4}$

I expect that her education negatively relates to union dissolution tolerance since higher educated couples will be more capable to break through the social and economic barriers and divorce stigma (education has a 'liberating' effect (Blossfeld et al. 1995)). Regarding commitment, my expectation is less clear: on the one hand, higher educated couples may be less committed due to their (economically) more independent position (Becker 1981), on the other hand, selection effects may lead to a pattern of more committed couples among the higher educated because these couples take longer before they form a union (Blossfeld and Huinink 1991). I expect that union dissolution tolerance is positively associated to break up and commitment negatively.

\subsubsection{General Hypotheses on Attractions and Barriers}

As presented in Fig. 5.1a, I expect that attractions, like family income, nondeprivation, his social status, age and educational homogamy, and relationship satisfaction are indicative for a lower break-up rate of the couple. Assuming that her education is associated to all of these rewards (symbolic, material, and affectional) (perhaps with the exception of educational/age (dis)similarity), her higher education is expected to lead to a lower break-up rate due to the higher attractions to stay together (H1). In contrast (see Fig. 5.1b), I expect lower barriers to be related to her education because higher education might go together with less material and symbolic costs to break-up (for affectional costs, I do not have an expectation). I expect that her higher education is related to higher break-up rates because she has lower barriers (costs) to disrupt the relationship (H2) (and thus barriers suppress the negative educational gradient of union dissolution).

\footnotetext{
${ }^{3}$ Obviously, religious dissimilarity may play a role (it can be a source of attitudinal dissimilarity for instance), but I cannot study this, as in the GGS the religious denomination of the spouse is not asked for.

${ }^{4}$ Note that in the case of public support for a break up, the separation risk of the couple could be higher since in that case they would adhere to the then present social norm.
} 


\subsubsection{The Observed Context}

I pool and compare six countries that differ remarkably on their divorce rate (access to divorce) and welfare state provision. The first component was found to be important by Matysiak et al. (2014) in their meta-analysis on European countries. The latter one is considered to be a prominent (cluster of) cross-national explanatory factors by Puur et al. (2016). Note, however, that others have found that in more generous welfare states the educational gradient more often is positive rather than negative (Härkönen and Dronkers 2006), although their expectation was otherwise. Generous welfare state benefits and services were expected to increase women's economic independence, which is especially beneficial for the lower educated who might then take the decision to break up more easily.

In Table 5.1, the Crude Divorce Rate (CDR), the female labour force participation rate, institutional child care support for working mothers, and single parent allowances are shown for 2005 (if available for that year). In Russia, the CDR is highest, followed by Czech Republic, France, and Austria respectively. In Bulgaria and especially in Georgia, the CDR is low. A better indicator of the divorce rate in a country is the Total Divorce Rate (TDR) (not presented) and this indicator gives a similar country ordering (no data available for Georgia and Russia).

I expect that a combination of divorce access (represented by the CDR, an indication of the social costs of divorce) and welfare state generosity (indicating the economic costs of divorce) will guide the cross-national differences I might find in the extent of educational differences in union dissolution rates. Lower social and economic costs of divorce will be related to a more negative educational gradient as the barriers to break up for the lower educated are reduced in such societies. I expect that the negative gradient is strongest in Czech Republic, Austria, and France, where both access to divorce and welfare state provisions are ample, followed by Russia, which has high access to divorce but low welfare state provisions compared to the other countries. The weakest gradient I expect in Bulgaria and Georgia, where both access to divorce and welfare state provisions are low (H3).

\subsection{Data, Operationalization, and Method}

I use the first two waves of the Generations and Gender Survey (GGS) to explain educational differences in union disruption. Eleven European countries have participated in two waves of this survey, but I selected only six countries because of their large variation in the divorce rate (Table 5.1, column 1) and the availability of mediating variables. ${ }^{5}$ The first wave was held in the period 2004 to 2009 (the year varies

\footnotetext{
${ }^{5}$ In Germany and Italy, information about durables and church attendance was not asked. In the Netherlands, the degree of urbanization, the age of the children, and the item about marriage is an outdated institution were not asked; in Hungary, church attendance, degree of urbanization, and conflict resolution skills not. In Lithuania, the low educated category was so small that I could not compare it to the other categories $(\mathrm{N}=13)$. Moreover, variables such as male and female unem-
} 
Table 5.1 Divorce access and welfare state provisions for six GGS countries

\begin{tabular}{|c|c|c|c|c|c|c|c|}
\hline & $\begin{array}{l}\text { Crude } \\
\text { divorce } \\
\text { Rate } \\
(C D R) \\
(2005)^{\mathrm{a}} \\
\end{array}$ & $\begin{array}{l}\text { Age } \\
\text { standardized } \\
\text { female labour } \\
\text { force } \\
\text { participation } \\
\text { rate }(2005)^{\mathrm{b}} \\
\end{array}$ & $\begin{array}{l}\text { Daily } \\
\text { school } \\
\text { hours } \\
\text { primary } \\
\text { school } \\
(2003)^{c} \\
\end{array}$ & $\begin{array}{l}\text { Child care } \\
\text { coverage } \\
\text { rates for } \\
\text { pre-school } \\
\text { children } \\
(3-6) \\
(2000)^{\mathrm{d}}\end{array}$ & $\begin{array}{l}\text { Maternity } \\
\text { leave (no } \\
\text { of paid } \\
\text { weeks) } \\
(2002)^{\mathrm{e}}\end{array}$ & $\begin{array}{l}\text { Parental } \\
\text { leave (no } \\
\text { of paid } \\
\text { weeks) } \\
(2005)^{\mathrm{f}}\end{array}$ & $\begin{array}{l}\text { Monthly } \\
\text { social } \\
\text { assistance } \\
\text { for lone } \\
\text { parent with } \\
\text { two children } \\
(2001)^{\mathrm{g}}\end{array}$ \\
\hline $\mathrm{CZ}$ & 3.1 & 79 & 9 & 85 & 28 & 156 & 651 \\
\hline AT & 2.4 & 80 & $5.4^{\mathrm{h}}$ & 68 & 16 & 104 & $1300^{p}$ \\
\hline FR & 2.5 & 80 & 7 & 99 & 16 & 156 & $913^{q}$ \\
\hline $\mathrm{RU}$ & 4.2 & 82 & $6^{\mathrm{i}}$ & 68 & $18^{\mathrm{k}}$ & $78^{\mathrm{m}}$ & \\
\hline BG & 1.9 & 72 & $\begin{array}{l}\text { Half/full } \\
\text { dayj }\end{array}$ & 67 & 19 & $104^{\mathrm{n}}$ & N.A. \\
\hline GE & 0.4 & 65 & & 28 & $18^{1}$ & $50^{\circ}$ & N.A. ${ }^{r}$ \\
\hline
\end{tabular}

aSources: Demographic Yearbook United Nations

'International Labour Organization, 2005 (Key Indicators of the Labour Market): derived January 18, 2018 from http://kilm.ilo.org/KILMnetBeta/default2.asp

'Family Policy Database, version 2 (2003): own calculations: weekly hours/5, 2003 (retrieved April 29, 2010)

dOECD(2001); RU, BG, GE: TransMONEE 2007 Database, UNICEF (2007) (retrieved $29 / 06 / 2010)$

${ }^{\mathrm{e}}$ www.cesifo-group.de/ifoHome/facts/DICE/Social-Policy/...mat.../Dur-mat-lea.xls (retrieved May 23, 2018)

${ }^{f}$ OECD family database http://www.oecd.org/els/family/database.htm (retrieved 29/06/2010); RU, BG: The Clearinghouse on International Developments on Child, Youth and Family Policies (2004)

${ }^{\mathrm{g}}$ Average monthly amounts. Including housing costs, special needs benefits and occasional payments. SaMip: Social Assistance and Minimum Income Protection Dataset (SAMIP), provided as part of the Social Policy Indicator Database (SPIN). http://www.spin.su.se/datasets/samip. National currency MIP's for lone parents are converted into PPP's (dollars) based on https://data. oecd.org/conversion/purchasing-power-parities-ppp.htm (retrieved May 7, 2018)

hhttp://www.expatfocus.com/expatriate-austria-education-schools

ihttps://www.justlanded.com/english/Russia/Russia-Guide/Education/Russian-Schools

jEurydice: https://webgate.ec.europa.eu/fpfis/mwikis/eurydice/index.php/Bulgaria:Organisation_ of_Early_Childhood_Education_and_Care

${ }^{\mathrm{k}}$ Gerber and Perelli-Harris (2012)

'https://onlinelibrary.wiley.com/doi/epdf/10.1111/issr.12128 and correspondence with Dimitri Gugushvili (May 20, 2018)

${ }^{\mathrm{m}}$ Data for 2000. After 28 weeks minimum wage instead of $100 \%$ payment

nData for 2000. After 6 months minimum wage instead of $90 \%$ payment

'https://en.wikipedia.org/wiki/Parental_leave\#Europe_and_Central_Asia (retrieved May 7, 2018)

${ }^{\mathrm{P} A u s t r i a n}$ schilling expressed in US dollars, current rate

${ }^{q}$ French francs expressed in US dollars, current rate

${ }^{\mathrm{r}}$ Correspondence with Dimitri Gugushvili (May 20, 2018) 
per country, but mostly in 2004 or 2005) and the second wave in 2007-2013 (mostly 2007). The units of analyses are women (aged 18-45 years) ${ }^{6}$ in couples who live with a spouse/partner in the same household (and none of them is not enrolled in education as a main activity) ( $\mathrm{N}$ coupled women $=8599)$. After list wise deletion of missing cases on independent variables I am left with 7086 cases $(\mathrm{N}=322$ separations). I weight the data so that each of the six countries has equal weight in the country fixed effects models.

I operationalize the dependent variable as a break up (of a marriage or cohabitation) between the two consecutive waves based on the question in the partnership history of what happened with the partnership of wave 1 (currently living together, broke up, partner died). In Austria, about 10\% break up, in Russia 7.0\%, in France $7.7 \%$, in Czech Republic 5.5\%, in Bulgaria 1.6\%, and in Georgia 0.8\%. ${ }^{7}$ Female education is measured in 7 ISCED categories and recoded into three-categorical variables: $0 / 1 / 2=$ low (reference category); $3 / 4=\mathrm{mid} ; 5 / 6=$ high. This was necessary because of the comparability of the measure between the different countries and the rather small sample sizes. In Table 5.2 are the mediating variables (attractions and barriers) listed with their operationalization and descriptives. I also included the following concomitant variables: age at union formation, union duration, whether cohabiting (before marriage), mother's educational level, and working hours. Note that I also included a 'missingness' category for the social status variables (imputed by the average ISEI on the status variable itself) and for conflict resolution skills (18\% of the cases was missing).

To analyse to what extent I can explain the negative female educational gradient of union dissolution by mediating variables, I use the khb-decomposition (KarlsonHolm-Breen) (Breen et al. 2013; Karlson et al. 2012) for nested nonlinear probability models. This technique takes into account the rescaling of the variance of the dichotomous dependent variable (Mood 2010) when more variables are introduced into the model and hence decomposes the total effect into a mediation and a rescaling effect. It corrects the scale of the dependent variable of the reduced model (which is the model without the mediator(s)) by including the residual of the confounding variable(s) predicted by the main independent variable instead of the confounding variable itself. ${ }^{8}$ By doing so, the method rescales the reduced equation to

ployment, educational similarity/male hypergamy, whether missing on conflict resolution skills, and parental divorce could not be included due to small sample sizes per cell.

${ }^{6}$ There are very few separations among women older than 45 years in the countries studied. Moreover, for Austria women older than 45 were not part of the sample. When excluding Austria and performing the analyses on the sample of women aged 80- years, I find a similar size of the educational gradient and similar mediation effects, apart from missingness on the communication skills variables; that mediating effect dissapears (see discussion of results further on).

${ }^{7}$ This shows that either the CDR is not a reliable measure of the likelihood to break up in a country and one can better rely on the TDR, or the GGS data have a coverage problem (are not representative) because the CDR in Russia and Czech Republic is much higher than in Austria, contrary to what I find here with the GGS data.

${ }^{8}$ Note that the concomitant variables are just control variables, in the sense that they are included in both the reduced and the full model, but their residual is not calculated and included in the reduced model. 
Table 5.2 Description of dependent, mediating and confounding variables explaining the negative female educational gradient of union dissolution

\begin{tabular}{l|l|l|l}
\hline & & & $\begin{array}{l}\text { Standard } \\
\text { deviation (in } \\
\text { case of } \\
\text { non- } \\
\text { dichotomous } \\
\text { variable) }\end{array}$ \\
\hline Break up & $\begin{array}{l}\text { Rescription } \\
\text { Rooting after the question whether respondent is } \\
\text { now living together with the same partner/ spouse } \\
\text { with whom (s)he lived in [month year of first } \\
\text { wave]? - > What happened with this partnership? } \\
\text { (1) Currently living together; (2) Broke up; (3) } \\
\text { Partner died. Recode (1) into (0), (2) into (1) and } \\
\text { (3) into (missing) }\end{array}$ & 0.05 & \\
\hline
\end{tabular}

\begin{tabular}{|c|c|c|c|}
\hline \multicolumn{4}{|l|}{ Attractions } \\
\hline \multicolumn{4}{|c|}{ Affectional rewards } \\
\hline $\begin{array}{l}\text { Relationship } \\
\text { satisfaction }\end{array}$ & $\begin{array}{l}\text { How satisfied are you with your relationship with } \\
\text { your partner/spouse? Not at all satisfied (0) to } \\
\text { completely satisfied (10) }\end{array}$ & 8.47 & 1.81 \\
\hline \multicolumn{4}{|c|}{ Material rewards } \\
\hline Family income & $\begin{array}{l}\text { Approximate range of the net monthly income of } \\
\text { your household: (1) } 499 \text { euro or less; (2) 500-999 } \\
\text { euro; (3) 1000-1499 euro; (4) 1500-1999 euro: } \\
\text { (5) 2000-2499 euro; (6) 2500-2999 euro; (7) } \\
\text { 3000-4999 euro; (8) 5000 euro or more }\end{array}$ & 3.29 & 2.41 \\
\hline $\begin{array}{l}\text { Possession } \\
\text { durables }\end{array}$ & $\begin{array}{l}\text { Things household possesses and can afford: Color } \\
\text { TV; Video recorder/DVD player; Washing } \\
\text { machine; Microwave; Home computer; } \\
\text { Dishwasher; Telephone (whether fixed/mobile); } \\
\text { Car/van available for private use. (1) yes; (2) } \\
\text { would like but cannot afford; (3) do not have for } \\
\text { other reasons. Recode (2) into (1) and the other } \\
\text { categories into (0). Average score of } 8 \text { items }\end{array}$ & 0.20 & 0.27 \\
\hline $\begin{array}{l}\text { His } \\
\text { unemployment }\end{array}$ & $\begin{array}{l}\text { Respondents' or spouses' reported activity status } \\
\text { is unemployed (males) }\end{array}$ & 0.10 & \\
\hline \multicolumn{4}{|c|}{ Symbolic rewards } \\
\hline $\begin{array}{l}\text { Education male } \\
\text { partner }\end{array}$ & $\begin{array}{l}\text { Categorized ISCED scale into (1) low (ISCED } \\
\text { 0/1/2) (ref cat); (2) medium (ISCED3/4); (3) high } \\
\text { (ISCED 5/6) }\end{array}$ & $\begin{array}{l}0.13 \\
0.56 \\
0.31\end{array}$ & \\
\hline $\begin{array}{l}\text { Educational } \\
\text { similarity of the } \\
\text { couple }\end{array}$ & $\begin{array}{l}\text { (1) Female education > male education (ref. cat); } \\
\text { (2); homogamous; (3) Male education > female } \\
\text { education (Use of } 7 \text { category ISCED variable) }\end{array}$ & $\begin{array}{l}0.24 \\
0.55 \\
0.21\end{array}$ & \\
\hline $\begin{array}{l}\text { (Higher) } \\
\text { occupational } \\
\text { status male } \\
\text { partner }\end{array}$ & $\begin{array}{l}\text { ISEI (code 16-90) derived from ISCO. Those that } \\
\text { were not having a job at all (also not in the } 3 \text { years } \\
\text { before) were given the imputed average ISEI } \\
\text { score. }\end{array}$ & 41 & 15 \\
\hline $\begin{array}{l}\text { Age similarity of } \\
\text { the couple }\end{array}$ & Age respondent (wife) - age partner (husband) & -3.32 & 4.45 \\
\hline
\end{tabular}


Table 5.2 (continued)

\begin{tabular}{|c|c|c|c|}
\hline & Description & Mean & $\begin{array}{l}\text { Standard } \\
\text { deviation (in } \\
\text { case of } \\
\text { non- } \\
\text { dichotomous } \\
\text { variable) }\end{array}$ \\
\hline $\begin{array}{l}\text { Conflict } \\
\text { resolution skills: } \\
\text { talk }\end{array}$ & $\begin{array}{l}\text { Kind of reaction on disagreement: 'Keep your } \\
\text { opinion to yourself', five-point scale ranging from } \\
\text { (1) never to (5) very frequently. This item is } \\
\text { mirrored so that a higher score corresponds to } \\
\text { talking about a disagreement and never keep } \\
\text { opinion to oneself. Missing values are imputed by } \\
\text { the mode. }\end{array}$ & 3.55 & 1.09 \\
\hline $\begin{array}{l}\text { Conflict } \\
\text { resolution skills: } \\
\text { discuss }\end{array}$ & $\begin{array}{l}\text { Kind of reaction on disagreement: 'Discuss your } \\
\text { disagreement calmly', five-point scale ranging } \\
\text { from (1) never to (5) very frequently. Missing } \\
\text { values are imputed by the mode. }\end{array}$ & 3.54 & 0.97 \\
\hline $\begin{array}{l}\text { Conflict } \\
\text { resolution skills: } \\
\text { no shouting }\end{array}$ & $\begin{array}{l}\text { Kind of reaction on disagreement: 'Argue heatedly } \\
\text { or shout', five-point scale ranging from (1) never } \\
\text { to (5) very frequently. This item is mirrored so } \\
\text { that a higher score corresponds to never unheated } \\
\text { arguments. Missing values are imputed by the } \\
\text { mode. }\end{array}$ & 3.95 & 1.05 \\
\hline $\begin{array}{l}\text { Conflict } \\
\text { resolution skills: } \\
\text { no violence }\end{array}$ & $\begin{array}{l}\text { Kind of reaction on disagreement: 'End up } \\
\text { becoming violent', five-point scale ranging from } \\
\text { (1) never to (5) very frequently. This item is } \\
\text { mirrored so that a higher score corresponds to } \\
\text { never using violence. Missing values are imputed } \\
\text { by the mode. }\end{array}$ & 4.93 & 0.35 \\
\hline
\end{tabular}

Barriers

\begin{tabular}{|c|c|c|c|}
\hline \multicolumn{4}{|l|}{ Affectional costs } \\
\hline $\begin{array}{l}\text { Having young } \\
\text { children }\end{array}$ & Having children in the age between $0-6$ & 0.31 & \\
\hline \multicolumn{4}{|l|}{ Material costs } \\
\hline Home ownership & $\begin{array}{l}\text { Does your household own or rent this } \\
\text { accommodation or does it come rent-free? (1) } \\
\text { owner; (2) tenant or subtenant, paying rent; (3) } \\
\text { accommodation is provided rent-free; (4) other. } \\
\text { Collapsed into (0) non-owner; (1) owner }\end{array}$ & 0.69 & \\
\hline $\begin{array}{l}\text { (Lower) } \\
\text { occupational } \\
\text { status female }\end{array}$ & $\begin{array}{l}\text { ISEI (code 16-90) derived from ISCO. Those that } \\
\text { were not having a job at all (also not in the } 3 \text { years } \\
\text { before) were given the imputed average ISEI } \\
\text { score. }\end{array}$ & 62 & 15 \\
\hline $\begin{array}{l}\text { Her } \\
\text { unemployment }\end{array}$ & $\begin{array}{l}\text { Respondents' or spouses' reported activity status } \\
\text { is unemployed (females) }\end{array}$ & 0.10 & \\
\hline
\end{tabular}

Symbolic costs 
Table 5.2 (continued)

\begin{tabular}{|c|c|c|c|}
\hline & Description & Mean & $\begin{array}{l}\text { Standard } \\
\text { deviation (in } \\
\text { case of } \\
\text { non- } \\
\text { dichotomous } \\
\text { variable) }\end{array}$ \\
\hline $\begin{array}{l}\text { Relationship } \\
\text { commitment }\end{array}$ & $\begin{array}{l}\text { Response to item 'marriage is an outdated } \\
\text { institution': (1) strongly agree - (7) strongly } \\
\text { disagree }\end{array}$ & 3.83 & 1.00 \\
\hline $\begin{array}{l}\text { Number of } \\
\text { previous break } \\
\text { ups }\end{array}$ & $\begin{array}{l}\text { Number of previous break ups based on } \\
\text { partnership history and how the previous } \\
\text { partnerships (of those partners that have been } \\
\text { living together) have ended (1) broke up; (2) } \\
\text { partner died }\end{array}$ & 0.15 & 0.41 \\
\hline Parental divorce & $\begin{array}{l}\text { Did your biological parents ever break up? (1) } \\
\text { yes; (2) no; (3) no, they never lived together; (4) } \\
\text { no, other situation; (5) I do not know anything } \\
\text { about my parents. Collapsed into (0) no; (1) yes } \\
\text { (category (1) and (3)); (missing) (category (4) and } \\
\text { (5) and (missing or not applicable)) }\end{array}$ & 0.35 & \\
\hline Being religious & $\begin{array}{l}\text { Which religious denomination do you adhere to, if } \\
\text { any? (1)-( } 8 \text { ) denomination mentioned; ( } 9 \text { ) none. } \\
\text { Recoded into (0) no; (1) yes }\end{array}$ & 0.80 & \\
\hline $\begin{array}{l}\text { Church } \\
\text { attendance }\end{array}$ & $\begin{array}{l}\text { How often, if at all, do you attend religious } \\
\text { services (apart from weddings, funerals, baptisms, } \\
\text { and the like)? Frequency per year }\end{array}$ & 1.62 & 3.67 \\
\hline Rural area & $\begin{array}{l}\text { Type of settlement: (1) Rural; (2) Urban. Recoded } \\
\text { into (0) Urban; (1) Rural }\end{array}$ & 0.39 & \\
\hline
\end{tabular}

$\mathrm{N}=7086$

an Bulgaria, the amounts of the eight categories are in Bulgarian Lev's

the scale of the full equation and therefore the coefficients of the independent variable in the two models (reduced and full) can be subtracted from each other to get the direct effect. The method holds the error distribution constant between the full and the reduced model. Hence this method is unaffected by rescaling (i.e., changes in the variance of the error distribution) and by the changes in the shape of the error distribution across nested models.

I include the variables stepwise in the model to check if their contribution as an explanatory factor changes much when the model is more complex: first, I include all attractions together in the model (Tables 5.3a and 5.3b, 2nd and 3rd column). Then I examine a model with all barriers (Tables 5.3a and 5.3b, 5th and 6th column) (hence, no attractions). Subsequently, I get a very extensive model (with both attractions and barriers) which includes also many variables that are explaining less than $15 \%$ of the total negative educational difference (Tables 5.3a and 5.3b, 7th and 8th column). As a final model, I therefore estimate a more parsimonious model by delet- 
ing those variables from the model which explain less than $15 \% \mid$ of the total effect, which gives me the final model that I interpret (Tables 5.3a and 5.3b, final columns). I performed even more stepwise models than this, by including groups of attractions (e.g. only affectional rewards (relationship satisfaction), material rewards (his status, non-deprivation, or unemployment), and so on) or groups of barriers. I also checked all influences of each variable separately to detect problems with the inclusion of too many variables at the same time: the confounding effects in these very parsimonious models are mostly similar to the ones in the extensive final model (I will mention where this is not the case).

\subsection{Results}

\subsubsection{Khb-Mediation Analyses: Pooled Country Model}

Indeed, in the pooled country model (controlled for confounders ${ }^{9}$ ), I find a negative educational gradient (Tables 5.3a and 5.3b, first column). Both the difference between her mid education and low education $(-0.244)$ and the difference between her high education and low education $(-0.253)$ are negative (but both are not significant in the empty model). In other words: higher and mid educated women are less likely to break up than lower educated women. How can I explain this negative gradient? In the Tables, I first show the coefficients of the indirect effects of the mediating variables. (See the appendix for the decomposition of indirect effects into conditional direct effects of education $(\mathrm{X})$ on the mediators $(\mathrm{Z})$ and conditional direct effects of the mediators (Z) on separation (Y).) Thereafter, in the next column, I present the relative percentages that the indirect effects explain of the total effect of female education on union dissolution. In the discussion of the results, I will mainly refer to these percentages.

\subsubsection{Attractions}

Attractions do not explain the educational gradient but suppress it [by in total $-79 \%$ (sum of the third column with percentages explained by attractions, Table 5.3a) of the difference between middle and low education and $-106 \%$ (sum of the third column with percentages explained by attraction, Table 5.3b) of the difference between high and low education]. This is not in line with my hypothesis where I expected that attractions would mediate, but not suppress the negative educational gradient. I actually expected that barrier variables would be suppressors (the higher educated would experience lower barriers to breakup, which in turn would lead to

\footnotetext{
${ }^{9}$ These models are controlled for age at union formation, union duration and union duration squared, (premarital) cohabitation, education of the mother, and working hours.
} 


\begin{tabular}{|c|c|c|c|c|c|c|c|c|c|c|c|c|c|c|c|c|}
\hline & & 莺 & $8_{0}^{0}$ & & $\frac{80}{1}$ & & $\frac{8}{2}$ & & & $\begin{array}{l}0 \\
0 \\
0\end{array}$ & $\frac{8}{\frac{1}{1}}$ & & & & & $\frac{80}{1}$ \\
\hline 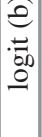 & $\begin{array}{l}\stackrel{*}{\stackrel{*}{+}} \\
\stackrel{+}{0} \\
i\end{array}$ & 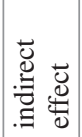 & 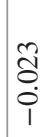 & & 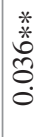 & & $\stackrel{0}{0}$ & & & \begin{tabular}{l} 
** \\
\multirow{*}{*}{} \\
$\stackrel{2}{0}$ \\
$\stackrel{0}{0}$
\end{tabular} & 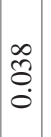 & & & & & 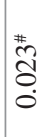 \\
\hline & & 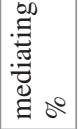 & $\begin{array}{l}0 \\
0 \\
0 \\
0 \\
1\end{array}$ & $\begin{array}{l}0 \\
0 \\
i \\
i \\
1\end{array}$ & $\frac{\infty}{1}$ & $\begin{array}{l}80 \\
\dot{+} \\
\text { in }\end{array}$ & $\mid \begin{array}{c}0 \\
0 \\
0 \\
1 \\
1\end{array}$ & $\frac{b^{\circ}}{15}$ & $\begin{array}{l}\stackrel{0}{2} \\
\text { ì } \\
\text { i }\end{array}$ & $\begin{array}{l}8_{0}^{\circ} \\
0 \\
1\end{array}$ & $\frac{\circ}{1}$ & $\begin{array}{l}\stackrel{0}{0} \\
\text { ஸे } \\
i\end{array}$ & $\frac{0^{0}}{0^{\circ}}$ & $\begin{array}{l}\stackrel{\circ}{\circ} \\
\stackrel{0}{0}\end{array}$ & $\frac{D^{\circ}}{\stackrel{1}{i}}$ & $\frac{0^{0}}{9}$ \\
\hline 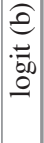 & 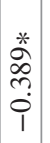 & 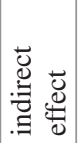 & $\begin{array}{l}\text { ปे } \\
0 \\
0 \\
1\end{array}$ & $\stackrel{n}{8}$ & $\stackrel{*}{*}$ & $\begin{array}{l}0 \\
0 \\
0 \\
1\end{array}$ & $\stackrel{\Xi}{\Xi}$ & $\begin{array}{l}1 \\
0 \\
0 \\
1\end{array}$ & $\stackrel{8}{8}$ & $\frac{*}{*}$ & \begin{tabular}{c}
$\infty$ \\
\hdashline \\
\hdashline \\
0 \\
0
\end{tabular} & $\stackrel{\bar{\delta}}{\circ}$ & $\begin{array}{l}8 \\
8 \\
0 \\
1\end{array}$ & $\begin{array}{l}8 \\
8 \\
0 \\
0 \\
1\end{array}$ & Oे. & 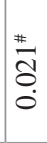 \\
\hline
\end{tabular}




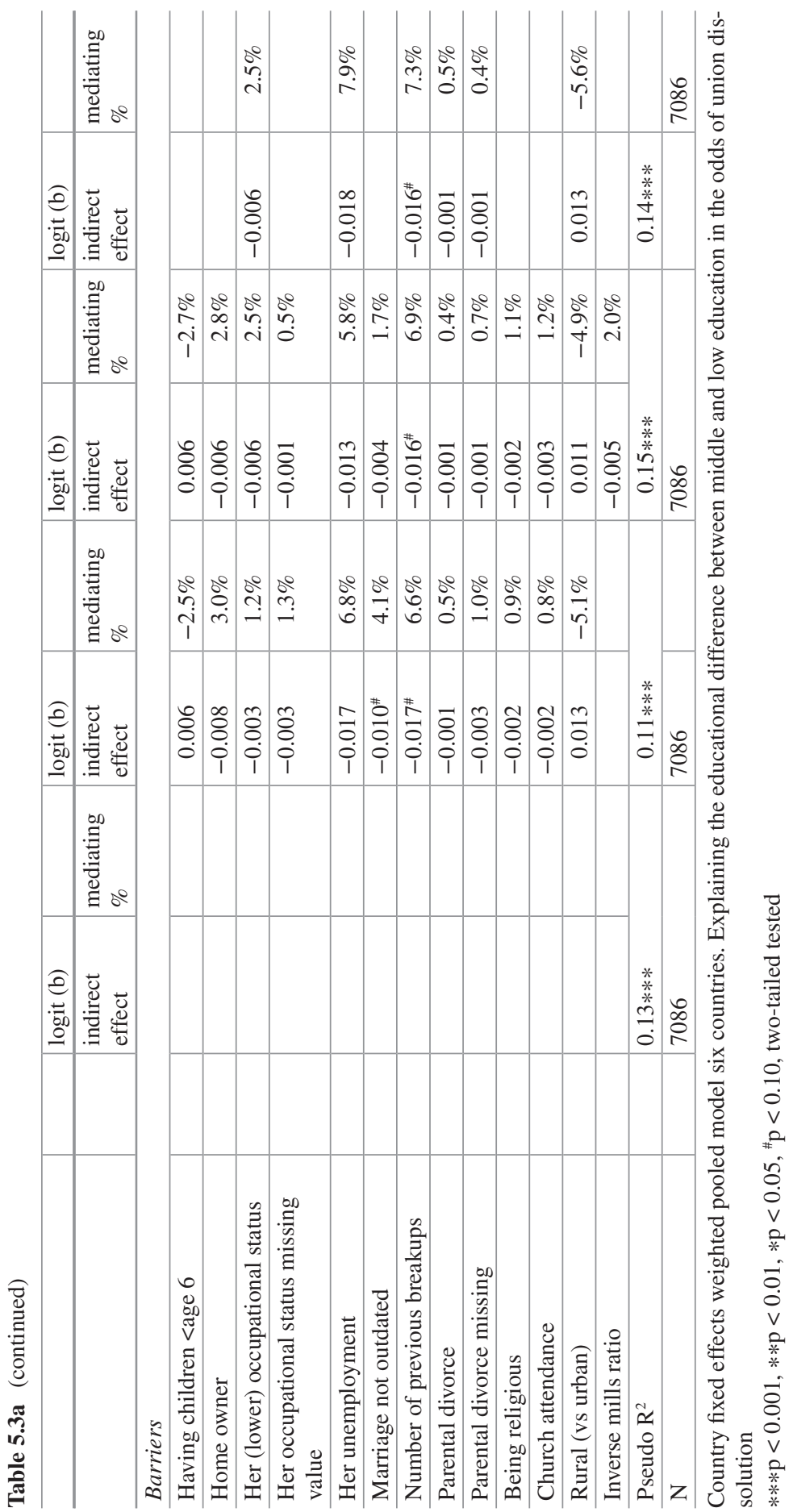




\begin{tabular}{|c|c|c|c|c|c|c|c|c|}
\hline & & 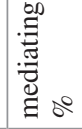 & $\begin{array}{l}\stackrel{2}{2} \\
\stackrel{2}{7}\end{array}$ & $\begin{array}{c}0 \\
\frac{0}{1} \\
\frac{1}{1}\end{array}$ & $\stackrel{\frac{0}{\imath}}{i}$ & $\begin{array}{l}1 \\
\frac{8}{8} \\
\frac{8}{1}\end{array}$ & i̊ & $\frac{8}{7}$ \\
\hline $\begin{array}{l}\hat{\varrho} \\
.0 \\
0 \\
0 \\
0\end{array}$ & 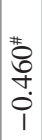 & 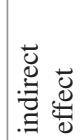 & \begin{tabular}{l}
$*$ \\
$*$ \\
$*$ \\
\multirow{2}{*}{} \\
0 \\
0 \\
1
\end{tabular} & $\begin{array}{l}\frac{*}{*} \\
\stackrel{*}{5} \\
\vdots \\
0\end{array}$ & $\begin{array}{l}\infty \\
\ddot{b} \\
0 \\
0\end{array}$ & 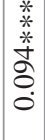 & $\begin{array}{l} \pm \\
\end{array}$ & 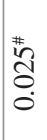 \\
\hline
\end{tabular}

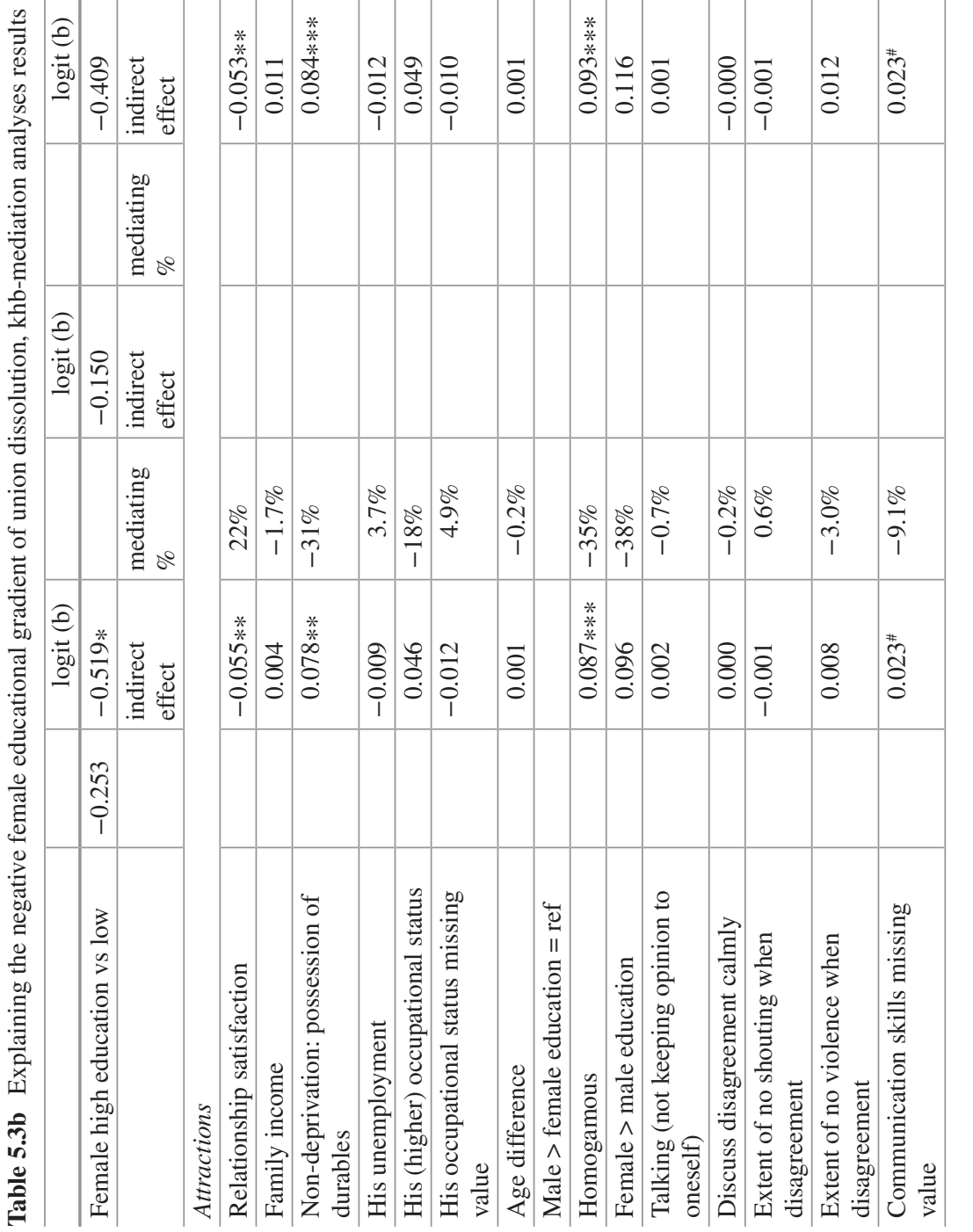




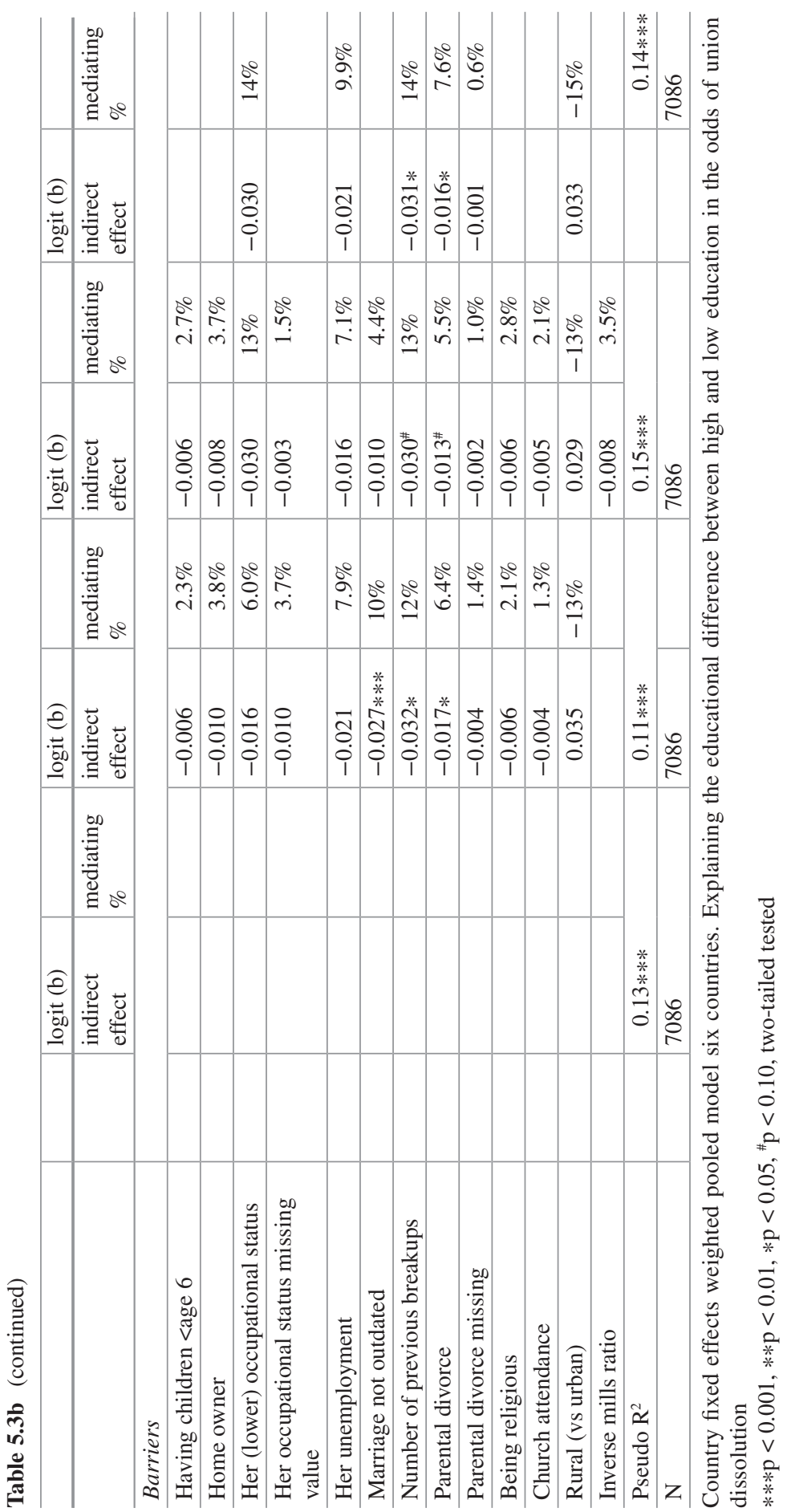


higher breakup rates among the higher educated compared to the lower educated). It turns out to be the other way around. This is especially due to including educational (dis)similarity ${ }^{10}$ (as opposed to having a traditional couple where his education is higher than hers) (e.g. $-51 \%$ of the difference between mid and low education in break-up rates is explained by homogamous couples vs. male hypergamous couples. For the difference between high and low education the explanatory percentage is $-35 \%$ ). This means that educationally homogamous couples are significantly more likely to break up than traditional ones [see e.g. Table 5.5b with conditional direct effect of $0.205 * * *$ of educational level on educational constellation (homogamy vs male hypergamy in this case)] and because the association between her educational level and whether or not being homogamous is positive ( $0.459 * *)$, homogamy suppresses the negative educational gradient of divorce (the coefficient of the remaining direct effect is more negative than without controlling for educational constellation). ${ }^{11}$ In other words, if one could take into account the fact that her higher or middle high education very often does not go together with stable traditionally specialized couples, the stability of (middle- or) higher educated couples would have been even greater.

Next to the suppressor effect of educational (dis)similarity as a symbolic reward, material rewards in the form of non-deprivation is an important suppressor variable (non-deprivation increases the educational differences by $16 \%$ or $31 \%$ respectively). Another remarkable result is that having a missing value on communication skills suppresses the negative educational gradient of union dissolution: when respondents do not answer on at least one of the conflict resolution skills variables, they are less likely to separate. And because a missing value on communication skills occurs less frequently among the higher educated, the indirect effect of having a missing value on communication skills is positive. I am unsure how to interpret this suppressor effect of having a missing value on conflict resolution skills. It might be that people on purpose skip these questions because they would score 'badly' on them. But skipping at least one of these questions might also just have been a mistake without any meaning. Therefore, I leave it to future research to find out what it is about communication skills' missing values that suppresses the negative educational gradient of separation. Moreover, one measure of attractions, relationship satisfaction, explains part of the educational gradient of union dissolution (by $9.4 \%$ or $22 \%$ respectively).

\footnotetext{
${ }^{10}$ Unfortunately, I cannot take both his education and educational dissimilarity into account in one model, as this would lead to multicollinearity. Since educational (dis)similarity contributed more to the explanation of union dissolution than his education, I chose to continue with educational (dis)similarity only. A model where I included his education instead of educational (dis)similarity showed that his higher education suppresses the female negative gradient. Including his education instead of (dis)similarity did not change the effect sizes of the other mediators much.

${ }^{11}$ Excluding educational (dis)similarity changes the results only slightly: The sizes of all the mediating effects remain more or less the same. However, the total suppressive indirect effect of attractions changes substantially: The total explanatory effect of attractions is in this case $-22 \%$ (mid-low educational difference) and $-40 \%$ (high-low educational difference).
} 


\subsubsection{Barriers}

Barriers contribute in total $19 \%$ (middle vs low) and $44 \%$ (high vs low) to the explanation of the negative educational gradient of union dissolution [these percentages are the sum of column five in Table 5.3a (19\%) and Table 5.3b (44\%)]. Here, symbolic costs significantly play a role ${ }^{12}$ : the barrier of commitment explains/confounds a part of the (high-low) educational gradient (10\%), just like the barrier of tolerance of divorce (number of previous breakups: $12 \%$ and parental divorce $(6.4 \%))$.

\subsubsection{The Extensive Model}

When including both attractions and barriers together, I see only slight changes in the indirect effects. The only remarkable differences are the increasingly mediating effect of women's lower occupational status (from $6 \%$ to $13 \%$ Table $5.3 \mathrm{~b}$ ) and the decreasing mediating effect of commitment to marriage (from $10 \%$ to $4.4 \%$ Table 5.3b). An attempt to control for selection into partnership is done by including the Inverse Mills Ratio (IMR) of a probit explaining couple formation out of religiosity, age and age $^{2}$, mothers' educational level, working hours, parental divorce, and commitment to marriage ('marriage is an outdated institution') (see Appendix Table 5.6). Including the IMR does not change any of the above-described results, apart from the effect of the commitment variable (because I included this variable in the selection equation) (the extensive model without IMR is not presented here, but can be provided upon request). The explaining percentages of all attractions and barriers hardly change. The indirect effects of the IMR are negative $(-0.005$ and -0.008 respectively), which point to a weak impact of selection into couple formation as an explanation of the negative educational effect on union dissolution; the lower educated are more likely to select themselves into a co-residential partnership and those in a union are more likely to break up.

The importance of her (lower) occupational status (explaining 2.5\% or $13 \%$ respectively) seems to indicate that it is not economic independence that matters (would be a non-barrier to break up), but rather that women belonging to the lower economic strata apparently have less to lose (or they experience more (financial) stress (Conger and Elder 1994; Goode 1962; Oppenheimer 1997). If she is higher educated, she is less likely to have a lower status and having a lower status is positively related to the odds of separation (see Appendix Tables 5.5a and 5.5b). Together, this explains part of the negative difference in separation odds between the high/mid educated on the one hand and the low educated on the other.

\footnotetext{
${ }^{12}$ Note the time order here: Parental divorce affects education rather than the other way around.
} 


\subsubsection{The Parsimonious Model}

From all the mediating/confounding variables included in the model, several explain less than $15 \%$ of the total effect of education on separation and I estimate a more parsimonious model (based on the high-low educational difference) excluding those variables that contribute little to the explanation of the negative educational gradient (columns eight and nine of Tables 5.3a and 5.3b). Here one can see that the pattern of large suppression by attractions such as educational homogamy and material rewards remains and that affectional rewards (relationship satisfaction), symbolic barriers and some material costs (her lower occupational status) explain part of the educational gradient of union dissolution.

Overall, in the final parsimonious model, one could say that 'attractions' suppress $-144 \%$ of the total educational difference between high and low education in break up rate (sum of explaining percentages of attractions), while 'barriers' explain together $31 \%$ (sum of explaining percentages of barriers) (Table 5.3b). All variables together suppress the high-low difference by $-113 \%(-144 \%+31 \%)$. This is contrary to our hypotheses in which I expected that higher educated women would have more attractions from a relationship and therefore they would be less likely to break up (Note that this is true for relationship satisfaction, but not for other attractions). Here, however, I find that the higher educated have more barriers and that higher attractions are unexpectedly positively related to breaking up, instead of negatively. This is mainly due to the fact that homogamous couples are more likely to break up than traditional male hypergamous couples. For the mid-low educational difference the explaining percentages are $-100 \%$ for attractions, $13 \%$ for barriers, and a total suppression of all variables by $-87 \%$ (Table $5.3 \mathrm{a}$ ).

Note that these results barely change when I included each variable separately in a model to assess its explanatory value. ${ }^{13}$ The observed pattern remains more or less the same. The explained percentages change somewhat, but educational homogamy remains the most important suppressor and barriers are less important explanatory variables than attractions are suppressing the educational gradient.

\footnotetext{
${ }^{13}$ Only his unemployment is a more important explanatory variable, explaining $12-14 \%$ of the educational difference in the union dissolution odds. This indirect effect disappears after taking her relationship satisfaction into account, something that has also been found by Boertien and Härkönen (2018) in their path model (part of the mediation of his unemployment on divorce is via her marital satisfaction). The suppressor effects of educational homogamy are much smaller ( $-46 \%$ for the mid-low and $-29 \%$ for the high-low difference) and the influence of selection into the union that is captured by the IMR is somewhat larger (5-8\%).
} 


\subsubsection{Separate Country Models: Context Dependent Educational Differences}

In Table 5.4, I present the country specific educational gradients, both the reduced model (without mediating/confounding variables) and the full model (with the relevant variables - explaining more than $15 \% \mathrm{l}$ - included). Especially remarkable is the large positive educational gradient (full models coefficients: 0.878 and 0.800 , respectively) in Russia (excluding this country would lead to a stronger negative educational gradient). As expected, the difference between the high and the low educated is largest in Czech Republic ( -0.747$)$, followed by Georgia (unexpected) $(-0.606)$, France $(-0.563)$, and Austria (-0.539). The odds of union dissolution of the mid educated compared to the low educated are not always lower than the odds of break-up of the high educated compared to the low educated (see e.g. France). This is unexpected as well and needs further research in the respective countries. Note that I controlled the reduced models for age at union formation (which takes away part of the selection effect into partnership), union duration, whether cohabiting (before marriage), education of the mother, and working hours.

Would I have had enough power to do country analyses, then I could have compared the reduced with the full models to assess the influence of the indirect effects per country. However, I can only rely upon the pooled country model from above for mediation analyses.

Table 5.4 Cross-national comparison of explaining the negative female educational gradient of union dissolution, khb-mediation analyses results final models

\begin{tabular}{|c|c|c|c|c|c|c|c|}
\hline & BG & RU & GE & FR & AT & $\mathrm{CZ}$ & All \\
\hline \multicolumn{8}{|c|}{ Female mid education vs low } \\
\hline $\begin{array}{l}\text { Reduced } \\
\text { model }\end{array}$ & 0.264 & 1.506 & -0.057 & $-0.680 *$ & -0.253 & 0.136 & -0.224 \\
\hline Full model & 0.376 & 0.878 & 0.143 & $-1.050 * *$ & -0.335 & -0.448 & $-0.421 *$ \\
\hline \multicolumn{8}{|c|}{ Female high education vs low } \\
\hline $\begin{array}{l}\text { Reduced } \\
\text { model }\end{array}$ & -0.196 & $1.655 *$ & -0.136 & -0.277 & -0.459 & -0.591 & -0.216 \\
\hline Full model & 0.092 & 0.800 & -0.606 & -0.563 & -0.539 & -0.747 & $-0.460^{\#}$ \\
\hline $\begin{array}{l}\text { Pseudo } R^{2} \\
\text { full model }\end{array}$ & $0.13 * * *$ & $0.19 * * *$ & $0.27 * * *$ & $0.11 * * *$ & $0.14 * * *$ & $0.10 * * *$ & $0.14 * * *$ \\
\hline $\mathrm{N}$ & 2024 & 1093 & 1606 & 837 & 1145 & 381 & 7086 \\
\hline
\end{tabular}

$* * * \mathrm{p}<0.001, * * \mathrm{p}<0.01, * \mathrm{p}<0.05,{ }^{*} \mathrm{p}<0.10$, two-tailed tested

Ln(odds ratio's) break-up of marital and cohabitational relationships for six GGS countries (women's reports) 


\subsection{Conclusion and Discussion}

In this chapter, I explained the negative female educational gradient of union dissolution in the pooled model of six countries. I indeed found differences in the break-up rate of high educated women compared to low educated women, but this educational difference was only significant in the pooled country models after taking into account suppressor effects (of which homogamy was the most important). This means that the difference between high and low educated women in break-up rate is only statistically significant when I 'fairly' compare the low and high educated. Low educated women are more likely to be in a male hypergamous relationship, whereas high-educated women are more likely to be in a homogamous relationship. Because homogamous couples are more likely to break-up than traditional male hypergamous couples (see also Schwartz and Han 2014), I initially do not find a large negative difference between the high and the low educated women. This difference becomes only visible once I control for relative education.

Moreover, the negative gradient is context dependent, with the strongest negative gradient in Czech Republic and the least strong one in Georgia and Bulgaria, and Austria and France in between. Russia actually has a positive educational gradient. Apart from the Russian positive gradient and the relatively strong negative gradient in Georgia, this is what I expected based on country-differences in social and economic costs of divorce and separation.

Most importantly, I was interested in explaining women's educational influence by Levinger's suggested attractions of the relationship and barriers to break-up. Overall, I found that symbolic costs and her status position in society are important explanatory variables driving the effect of women's education on break up. Apparently, lower educated women (compared to higher educated) who have less to lose socially (as indicated by their lower commitment and higher divorce tolerance) and economically (as measured by their lower occupational status) are more likely to break-up in this sample of six countries. Note that this last finding goes against the commonly made argument in the literature of economic independence (e.g. Cherlin 1992; Oppenheimer 1997). The reason for this may be that men's economic position matters more, rather than women's economic position (e.g. Kalmijn 2011; McLanahan and Percheski 2008). Our mediation analyses also indicates this because men's employment situation affects break-up (completely) through relationship satisfaction (see footnote 13). Furthermore, more material rewards (husbands' social status and household non-deprivation), that I expected to play a role based on Levinger $(1965,1976)$ and Oppenheimer (1997), do not explain the negative gradient, but they suppress it. This can be explained as follows: women with higher education more often have partners with more economic resources. And because 
men's economic resources go together with higher odds of union dissolution (when controlling for some concomitant variables), I find that women with higher education are less likely to break-up when I control for men's economic resources. I also found a relatively important mediation effect of relationship satisfaction.

Overall, I could explain about half of the difference in union dissolution odds between high and low educated women. What is it that makes couples with higher female education more stable? Next to relationship satisfaction (which explains $25 \%$ ) this turns out to be costs or 'barriers' (symbolic costs and her socio-economic position - lower educated women have less of these costs to lose) (31\%). These findings are in line with Boertien and Härkönen $(2014,2018)$, although they found a less strong impact of relationship satisfaction. One difference between their study and mine is that they looked at divorces of marriages, whereas I also include breakups of cohabitational relationships. Another one is that they found important mediating effects of home ownership, which I do not find. This might have to do with the partly Eastern-European context I examine, where ownership of the house is common and often transmitted from one generation to the next.

This chapter has several limitations: first, I only examined women's educational level and her likelihood to break-up. Of course, her education could coincide with his education and it might actually be his education that matters more than hers. Future research would have to tell, but this study indicated that there is some overlap between his and her education, although relative education seemed to be more important than his education as a suppressing factor. Secondly, further research on context dependent explanations of the educational gradient of union dissolution needs to be done. I could not do that here because of the small sample sizes in each country, but the future GGP2020 data might provide some more insight.

To conclude, my study suggests that Goode might have been right in predicting that lower educated couples are less stable in principle because they experience more family strain. With the reduction of social and economic costs of divorce in European societies, divorce and separation have become available to all social strata, and nowadays occur even more frequently among the lower ones.

Acknowledgement This chapter benefited from the support of the Centre for Population, Family and Health (CPFH) at the University of Antwerp and the Flemish Agency of Innovation and Entrepreneurship (Grant number:140069), which enabled Open Access to this chapter. 


\section{Appendices}

Table 5.5a Ad Table 5.3a. Explaining the educational difference between mid and low education in the odds of union dissolution, khb-mediation analyses results

\begin{tabular}{|c|c|c|}
\hline & $\operatorname{logit}(b)$ & \\
\hline & $\mathrm{X}->\mathrm{Z}$ & $\mathrm{Z}->\mathrm{Y}$ \\
\hline Attractions & & \\
\hline Relationship satisfaction & 0.095 & $-0.239 * * *$ \\
\hline Family income & & \\
\hline Non-deprivation: possession of durables & $0.039 * * *$ & $0.943 *$ \\
\hline His unemployment & & \\
\hline His (higher) occupational status & $3.656 * * *$ & 0.004 \\
\hline His occupational status missing value & & \\
\hline Age difference & & \\
\hline Male $>$ female education $=$ ref & & \\
\hline Homogamous & $0.294 * * *$ & $0.459 * *$ \\
\hline Female $>$ male education & $0.148 * * *$ & 0.255 \\
\hline Talking (not keeping opinion to oneself) & & \\
\hline Discuss disagreement calmly & & \\
\hline Extent of no shouting when disagreement & & \\
\hline Extent of no violence when disagreement & & \\
\hline Communication skills missing value & $-0.042 * *$ & $-0.543^{\#}$ \\
\hline Barriers & & \\
\hline Having children <age 6 & & \\
\hline Home owner & & \\
\hline Her (lower) occupational status & -3.614 & 0.002 \\
\hline Her occupational status missing value & & \\
\hline Her unemployment & $-0.051 * * *$ & 0.343 \\
\hline Marriage not outdated & & \\
\hline Number of previous breakups & $-0.071 * * *$ & $0.232^{\#}$ \\
\hline Parental divorce & -0.003 & $0.324 *$ \\
\hline Parental divorce missing & 0.013 & -0.074 \\
\hline Being religious & & \\
\hline Church attendance & & \\
\hline Rural (vs urban) & $-0.071 * *$ & -0.176 \\
\hline Inverse mills ratio & & \\
\hline Pseudo $\mathrm{R}^{2}$ & Based on different models & $0.14 * * *$ \\
\hline $\mathrm{N}$ & 7086 & \\
\hline
\end{tabular}

Country fixed effects weighted pooled model six countries. Explaining the educational difference between middle and low education in the odds of union dissolution. Decomposition of indirect effect

$* * * \mathrm{p}<0.001, * * \mathrm{p}<0.01, * \mathrm{p}<0.05,{ }^{*} \mathrm{p}<0.10$, two-tailed tested. Note that due tounding the product of $\mathrm{X}->\mathrm{Z}$ and $\mathrm{Z}->\mathrm{Y}$ does not always exactly equal the indirect effect presented in Table 5.3a 
Table 5.5b Ad Table 5.3b. Explaining the educational difference between high and low education in the odds of union dissolution, khb-mediation analyses results

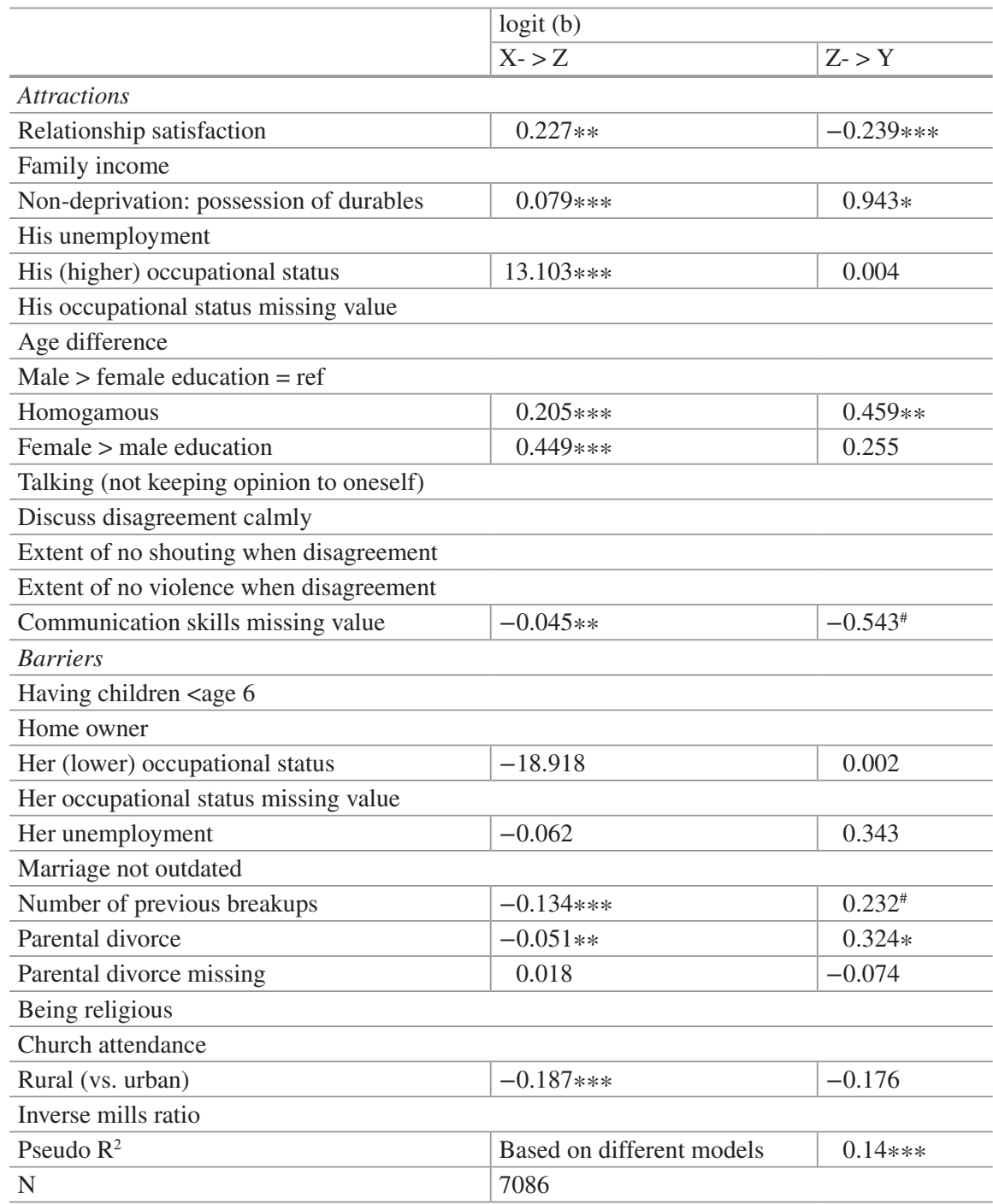

Country fixed effects weighted pooled model six countries. Explaining the educational difference between high and low education in the odds of union dissolution $* * * \mathrm{p}<0.001, * * \mathrm{p}<0.01, * \mathrm{p}<0.05,{ }^{*} \mathrm{p}<0.10$, two-tailed tested. Note that due to rounding the product of $\mathrm{X}->\mathrm{Z}$ and $\mathrm{Z}->\mathrm{Y}$ does not always exactly equal the indirect effect presented in Table 5.3b 
Table 5.6 Selection model of partnership formation, six countries, GGS

\begin{tabular}{|c|c|}
\hline & $\mathrm{b}$ \\
\hline \multirow[t]{2}{*}{ Mid education } & 0.018 \\
\hline & $(0.029)$ \\
\hline \multirow[t]{2}{*}{ High education } & -0.009 \\
\hline & $(0.033)$ \\
\hline \multirow[t]{2}{*}{ Religious } & -0.012 \\
\hline & $(0.035)$ \\
\hline \multirow[t]{2}{*}{ Age } & $0.141 * * *$ \\
\hline & $(0.004)$ \\
\hline \multirow[t]{2}{*}{$\mathrm{Age}^{2}$} & $-0.002 * * *$ \\
\hline & $(0.000)$ \\
\hline \multirow[t]{2}{*}{ Mid education mother } & $-0.075 * *$ \\
\hline & $(0.028)$ \\
\hline \multirow[t]{2}{*}{ High education mother } & $-0.156 * * *$ \\
\hline & $(0.038)$ \\
\hline \multirow[t]{2}{*}{ Education mother missing } & -0.057 \\
\hline & $(0.036)$ \\
\hline \multirow[t]{2}{*}{ Working hours } & -0.000 \\
\hline & $(0.001)$ \\
\hline \multirow[t]{2}{*}{ Parental divorce } & $-0.156 * * *$ \\
\hline & $(0.030)$ \\
\hline \multirow[t]{2}{*}{ Parental divorce missing } & 0.027 \\
\hline & $(0.060)$ \\
\hline \multirow[t]{2}{*}{ Marriage is outdated } & $0.130 * * *$ \\
\hline & $(0.010)$ \\
\hline \multirow[t]{2}{*}{ Russia } & $-0.410 * * *$ \\
\hline & $(0.028)$ \\
\hline \multirow[t]{2}{*}{ Georgia } & $-0.194 * * *$ \\
\hline & $(0.029)$ \\
\hline \multirow[t]{2}{*}{ France } & $-0.282 * * *$ \\
\hline & $(0.030)$ \\
\hline \multirow[t]{2}{*}{ Austria } & $-0.279 * * *$ \\
\hline & $(0.035)$ \\
\hline \multirow[t]{2}{*}{ Czech Republic } & $-0.361 * * *$ \\
\hline & $(0.045)$ \\
\hline \multirow[t]{2}{*}{ Constant } & $-2.629 * * *$ \\
\hline & $(0.102)$ \\
\hline $\mathrm{Chi}^{2}(\mathrm{df})$ & $1904 * * *(17)$ \\
\hline
\end{tabular}




\section{References}

Amato, P. R. (1996). Explaining the intergenerational transmission of divorce. Journal of Marriage and Family, 58(3), 628-640. https://doi.org/10.2307/353723.

Becker, G. (1981). A treatise on the family. Cambridge: Harvard University Press.

Berrington, A., Stone, J., \& Beaujouan, E. (2015). Educational differences in timing and quantum of childbearing in Britain: A study of cohorts born 1940-1969. Demographic Research, 33, 26.

Blossfeld, H.-P., \& Huinink, J. (1991). Human capital investments or norms of role transition? How women's schooling and career affect the process of family formation. American Journal of Sociology, 97(1), 143-168.

Blossfeld, H.-P., De Rose, A., Hoem, J. M., \& Rowher, G. (1995). Education, modernization, and the risk of marriage disruption in Sweden, West Germany, and Italy. In K. Oppenheim Mason \& A.-M. Jensen (Eds.), Gender and family change in industrialized countries. Oxford: Oxford University Press.

Boertien, D., \& Härkönen, J. (2014). Less education, more divorce: Explaining the inverse relationship between women's education and divorce. Stockholm Research Reports in Demography, 2012, 11.

Boertien, D., \& Härkönen, J. (2018). Why does women's education stabilize marriages? The role of marital attraction and barriers to divorce. Demographic Research, 38, 1241-1276.

Breen, R., Karlson, K. B., \& Holm, A. (2013). Total, direct, and indirect effects in logit and probit models. Sociological Methods \& Research, 42(2), 164-191. https://doi. org/10.1177/0049124113494572.

Castro Martin, T. (2006). Women's education and fertility in Spain: The impact of educational attainment and of educational choice on first, second, and third births. Centro de Estudios Avanzados en Ciencias Sociales.

Cherlin, A. (1992). Marriage, divorce, remarriage. Cambridge: Harvard University Press.

Conger, R. D., \& Elder, G. H. (1994). Families in troubled times: Adapting to change in rural America. New York: Aldine de Gruyter.

Dronkers, J., \& Härkönen, J. (2008). The intergenerational transmission of divorce in crossnational perspective: Results from the fertility and family surveys. Population Studies, 62(3), 273-288. https://doi.org/10.1080/00324720802320475.

Gerber, T. P., \& Perelli-Harris, B. (2012). Maternity leave in turbulent times: Effects on labor market transitions and fertility in Russia, 1985-2000. Social Forces, 90(4), 1297-1322.

Goode, W. J. (1962). Marital satisfaction and instability: A cross-cultural class analysis of divorce rates. International Social Science Journal, 14, 507-526.

Grow, A., \& Van Bavel, J. (2015). Assortative mating and the reversal of gender inequality in education in Europe: An agent-based model. PLoS One, 10(6), e0127806. https://doi.org/10.1371/ journal.pone.0127806.

Härkönen, J., \& Dronkers, J. (2006). Stability and change in the educational gradient of divorce. A comparison of seventeen countries. European Sociological Review, 22, 501-517. https://doi. org/10.1093/esr/jcl011.

Högnäs, R. S., \& Carlson, M. J. (2010). Intergenerational relationships and union stability in fragile families. Journal of Marriage and the Family, 72(5), 1220-1233. https://doi. org/10.1111/j.1741-3737.2010.00760.x.

Jalovaara, M. (2001). Socio-economic status and divorce in first marriages in Finland 1991-93. Population Studies, 55(2), 119-133.

Kalmijn, M. (2011). The influence of men's income and employment on marriage and cohabitation: Testing oppenheimer's theory in Europe. European Journal of Population, 27(3), 269-293. 
Kalmijn, M., de Graaf, P. M., \& Janssen, J. P. G. (2005). Intermarriage and the risk of divorce in the Netherlands: The effects of differences in religion and in Nationality, 1974-94. Population Studies, 59(1), 71-85.

Karlson, K. B., Holm, A., \& Breen, R. (2012). Comparing regression coefficients between samesample nested models using logit and probit. Sociological Methodology, 42(1), 286-313. https://doi.org/10.1177/0081175012444861.

Karney, B. R., \& Bradbury, T. N. (1995). The longitudinal course of marital quality and stability: A review of theory, methods, and research. Psychological Bulletin, 118(1), 3-34. https://doi. org/10.1037/0033-2909.118.1.3.

Levinger, G. (1965). Marital cohesiveness and dissolution: An integrative review. Journal of Marriage and Family, 27(1), 19-28. https://doi.org/10.2307/349801.

Levinger, G. (1976). A social psychological perspective on marital dissolution. Journal of Social Issues, 32(1), 21-47. https://doi.org/10.1111/j.1540-4560.1976.tb02478.x.

Levinger, G. (1999). Duty toward whom? Reconsidering attractions and barriers as determinants of commitment in a relationship. In J. M. Adams \& W. H. Jones (Eds.), Handbook of interpersonal commitment and relationship stability. New York: Kluwer Academic/Plenum Publishers.

Liefbroer, A. C., \& Dourleijn, E. (2006). Unmarried cohabitation and union stability: Testing the role of diffusion using data from 16 European countries. Demography, 43(2), 203-221.

Matysiak, A., Styrc, M., \& Vignoli, D. (2014). The educational gradient in marital disruption: A meta-analysis of European research findings. Population Studies, 68(2), 197-215.

McLanahan, S., \& Percheski, C. (2008). Family structure and the reproduction of inequalities. Annual Review of Sociology, 34(1), 257-276. https://doi.org/10.1146/annurev. soc.34.040507.134549.

Mood, C. (2010). Logistic regression: Why we cannot do what we think we can do, and what we can do about it. European Sociological Review, 26(1), 67-82. https://doi.org/10.1093/esr/ jcp006.

Oppenheimer, V. K. (1997). Women's employment and the gain to marriage: The specialization and trading model. Annual Review of Sociology, 23, 431-453.

Petts, R. J. (2016). Religious homogamy, race/ethnicity, and parents' relationship stability. Sociological Focus, 49(3), 163-179. https://doi.org/10.1080/00380237.2016.1135027.

Poortman, A.-R., \& Lyngstad, T. H. (2007). Dissolution risks in first and higher order marital and cohabiting unions. Social Science Research, 36, 1431-1446. https://doi.org/10.1016/j. ssresearch.207.02.005.

Puur, A., Rahnu, L., Maslauskaite, A., \& Stankuniene, V. (2016). The transforming educational gradient in marital disruption in Northern Europe: A comparative study based on GGS data. Journal of Comparative Family Studies, 47(1), 87-109.

Raymo, J. M., Fukuda, S., \& Iwasawa, M. (2013). Educational differences in divorce in Japan. Demographic Research, 28(6), 177-206.

Sayer, L. C., \& Bianchi, S. M. (2000). Women's economic independence and the probability of divorce: A review and reexamination. Journal of Family Issues, 21(7), 906-943. https://doi. org/10.1177/019251300021007005.

Schwartz, C. R., \& Han, H. (2014). The reversal of the gender gap in education and trends in marital dissolution. American Sociological Review, 79(4), 605-629. https://doi. org/10.1177/0003122414539682.

Schwartz, C. R., \& Mare, R. D. (2005). Trends in educational assortative marriage from 1940 to 2003. Demography, 42(4), 621-646.

Sprecher, S., \& Felmlee, D. (1992). The influence of parents and friends on the quality and stability of romantic relationships: A three-wave longitudinal investigation. Journal of Marriage and Family, 54(4), 888-900. https://doi.org/10.2307/353170. 
van Damme, M., \& Dykstra, P. (2018). Spousal resources and relationship quality in eight European countries. Community, Work, and Family (Special issue on Developing a sustainable community, work, and family interface).

van Damme, M., \& Kalmijn, M. (2014). The dynamic relationships between union dissolution and women's employment: A life-history analysis of 16 countries. Social Science Research, 48(0), 261-278. https://doi.org/10.1016/j.ssresearch.2014.06.009.

Open Access This chapter is licensed under the terms of the Creative Commons Attribution 4.0 International License (http://creativecommons.org/licenses/by/4.0/), which permits use, sharing, adaptation, distribution and reproduction in any medium or format, as long as you give appropriate credit to the original author(s) and the source, provide a link to the Creative Commons license and indicate if changes were made.

The images or other third party material in this chapter are included in the chapter's Creative Commons license, unless indicated otherwise in a credit line to the material. If material is not included in the chapter's Creative Commons license and your intended use is not permitted by statutory regulation or exceeds the permitted use, you will need to obtain permission directly from the copyright holder.

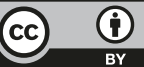

